\title{
Effect of Different Crop Establishment Methods and Fertilizer Sources on Growth, Yield Attribute and Yield of Rice (Oryza sativa L.)
}

\author{
D. N. Jagtap*, U. V. Mahadkar, L. S. Chavan, M. M. Burondkar, J. S. Dhekale, S. S. Dhane, S. S. Pinjari and M. S. Jadhav \\ Dr. Balasaheb Sawant Konkan Krishi Vidyapeeth, Dapoli, Maharashtra (415 712), India
}

\author{
Corresponding Author \\ D. N. Jagtap \\ e-mail: mauli296@gmail.com
}

\author{
Article History \\ Article ID: IJEP0269 \\ Received in $22^{\text {nd }}$ August, 2018 \\ Received in revised form $14^{\text {th }}$ October, 2018 \\ Accepted in final form $22^{\text {nd }}$ October, 2018
}

\begin{abstract}
The influence of different crop establishment methods and fertilizer sources on growth attributes and yield of rice was studied during Kharif season of 2009 and 2010 on lateritic soils. The experiment was laid out in split plot design replicate thrice with five crop establishment methods (transplanting, pre-monsoon dibbling of seeds, dibbling of seeds with the onset of monsoon, transplanting of seedling by Thomba method and system of rice intensification) in main plots and three fertilizer sources (recommended dose of fertilizers-120:60:60 kg NPK $\mathrm{ha}^{-1}$, placement of urea-DAP briquettes and placement of urea-suphala briquettes) in sub plots. From the present investigation, it can be concluded that for growing kharif rice under upland situation, crop need to be established by transplanting method and amended with urea-DAP briquettes (@168.75 $\mathrm{kg} \mathrm{ha}^{-1}$ ), to obtain higher yield. However, under inadequate rainwater for puddling, Thomba method with urea-DAP briquettes (@168.75 kg ha-1) is suitable, and under labour scarcity condition, pre-monsoon dibbling of seeds with urea-DAP briquettes (@168.75 kg ha-1) is one of the alternatives to conventional transplanting method under upland conditions.
\end{abstract}

Keywords: Urea-DAP briquettes, crop establishment methods and rice

\section{Introduction}

The average productivity of rice is $2.13 \mathrm{t} \mathrm{ha}^{-1}$ in India and $1.68 \mathrm{t} \mathrm{ha}^{-1}$ in Maharashtra, which is far below the World's average of $3.7 \mathrm{t} \mathrm{ha}^{-1}$. The productivity of rice is low due to delay in nursery sowing and late transplanting, faulty methods of cultivation and little or no use of fertilizers. The secret of boosting its yields mainly lies in timely transplanting and proper fertilization the crop. At the time of transplanting, availability of labourers is the main constraint in drilling of rice. However, the establishment of crop is very slow in drilling method result in low yields due to heavy weed infestation. Systematic studies on the performance of rice grown by direct seeding during premonsoon and post-monsoon in comparison with transplanting, Thomba method and SRI technique are not conducted in the region. Among various agronomic practices, judicious use of manures and fertilizers is one of the important strategies for increasing rice productivity. The improved varieties hybrids can give the anticipated yield, when grown under favourable environmental conditions including use of recommended dose of nutrients. Therefore, efficient fertilizer use has to be followed to increase the input use efficiency. On the other hand, the fertilizer use efficiency in transplanted rice is generally low. The straight fertilizers are no doubt important and easily available but their low availability to crop due to leaching and other losses lead to low yield. Therefore, it is necessary to optimize the use of slow release $\mathrm{N}$ fertilizers for higher yields and maintain the cost of production at reasonable level. Hence, the present investigation was undertaken to optimize nutrient management for different rice establishment methods.

\section{Materials and Methods}

A field experiment was conducted on Agronomy farm, College of Agriculture, Dapoli, Maharashtra during kharif, 2009 and 2010 to evaluate the response of hybrid rice (Sahyadri-4) to different crop establishment methods and sources of fertilizer application under Konkan upland situation. The experiment was laid out according split-plot design with three replications. Fifteen treatment conbinations comprised of five main plot treatments (transplanting, premonsoon dibbling of seeds, dibbling of seeds with the onset of monsoon, transplanting of seedlings by Thomba method, and System of Rice Intensification (SRI) and three subplot treatments RDF (120:60:60 kg NPK ha-1), placement of urea-DAP briquettes, and placement of urea-suphala briquettes). Dibbling of seeds was done before monsoon and on commencement of monsoon as per the treatment with the spacing of $15-25 \times 15$ $25 \mathrm{~cm}^{2}$ (row to rowxplant to plant). Thirty days old seedlings 
were transplanted in main field at spacing of $15-25 \times 15-25 \mathrm{~cm}^{2}$ in plots under transplanting and Thomba method. In Thomba method, seedlings were planted in the holes made by a pointed stick (Thomba) on ploughed field without carrying out the puddling operation. In SRI, healthy and vigorous seedlings were uprooted on 12 days after sowing. While uprooting, care was taken that seed remain attached to the seedlings along with the roots. One seedling was transplanted per hill at spacing of $20 \times 20 \mathrm{~cm}^{2}$. In RDF, $40 \% \mathrm{~N}$ and full dose of $\mathrm{P}$ and $\mathrm{K}$ were applied at the time of dibbling or transplanting. Remaining $40 \% \mathrm{~N}$ was applied at maximum tillering (30 DAT) and $20 \%$ at panicle initiation stage (65 DAT) as per the treatments. In case of briquettes fertilizers, briquettes were applied through deep placement method. Briquettes were manually placed at 5-6 cm soil depth @ one briquette for every four hills of rice. Urea-DAP briquettes (@ 168.75 kg ha- $\left.{ }^{1}\right)$ supplies $47.97 \mathrm{~kg} \mathrm{~N} \mathrm{ha}^{-1}$ and $32.04 \mathrm{~kg} \mathrm{P} \mathrm{ha}^{-1}$. Urea suphala briquettes (@168.75 kg ha-1) provide $46.69 \mathrm{~kg} \mathrm{~N} \mathrm{ha}^{-1}, 22.83 \mathrm{~kg}$ $\mathrm{P} \mathrm{ha}{ }^{-1}$ and $15.57 \mathrm{~kg} \mathrm{~K} \mathrm{ha}^{-1}$. Other cultural practices and plant protection measures were followed as per the recommended package of practice.

\section{Results and Discussion}

\subsection{Effect of crop establishment methods}

The growth and development parameters of rice viz.,

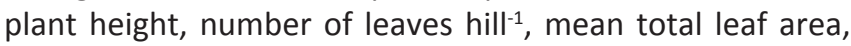
number of tillers hill ${ }^{-1}$ and dry matter accumulation hill ${ }^{-1}$ showed significant differences at harvesting stage due to crop establishment methods in rice during both the years (Table 1). At the time of harvest, plant height was maximum with transplanting followed by Thomba method but were on par with each other but were significantly superior to

Table 1: Plant height, number of functional leaves, number of tillers and total dry matter of rice at harvesting as influenced by different treatments

\begin{tabular}{|c|c|c|c|c|c|c|c|c|c|c|}
\hline \multirow[t]{2}{*}{ Treatment } & \multicolumn{2}{|c|}{$\begin{array}{l}\text { Plant height } \\
(\mathrm{cm}\end{array}$} & \multicolumn{2}{|c|}{$\begin{array}{l}\text { No. of function- } \\
\text { al leaves hill-1 }\end{array}$} & \multicolumn{2}{|c|}{$\begin{array}{l}\text { Leaf plant } \\
\text { area }\left(\mathrm{dm}^{2}\right)\end{array}$} & \multicolumn{2}{|c|}{$\begin{array}{l}\text { No. of } \\
\text { tillers }\end{array}$} & \multicolumn{2}{|c|}{$\begin{array}{l}\text { Total dry mat- } \\
\text { ter hill-1 (g) }\end{array}$} \\
\hline & 2009 & 2010 & 2009 & 2010 & 2009 & 2010 & 2009 & 2010 & 2009 & 2010 \\
\hline \multicolumn{11}{|l|}{ Crop establishment methods } \\
\hline $\mathrm{T}_{1}$-Transplanting & 77.4 & 82.5 & 14.2 & 18.3 & 5.40 & 6.97 & 9.7 & 11.7 & 44.6 & 48.6 \\
\hline $\mathrm{T}_{2}$-Pre monsoon dibbling of seeds & 72.5 & 77.5 & 9.1 & 13.1 & 3.46 & 4.98 & 7.4 & 9.4 & 39.4 & 43.1 \\
\hline $\begin{array}{l}T_{3} \text {-Dibbling of seeds on the onset of } \\
\text { monsoon }\end{array}$ & 72.2 & 77.5 & 7.0 & 11.1 & 2.66 & 4.22 & 6.1 & 8.0 & 37.6 & 41.2 \\
\hline $\mathrm{T}_{4}$-Thomba method & 77.0 & 82.7 & 14.0 & 18.1 & 5.32 & 6.88 & 9.4 & 11.4 & 43.0 & 46.8 \\
\hline $\mathrm{T}_{5}-\mathrm{SRI}$ technique & 70.1 & 75.8 & 11.8 & 15.9 & 4.48 & 6.04 & 9.6 & 11.6 & 42.8 & 46.6 \\
\hline $\operatorname{CD}(p=0.05)$ & 3.9 & 4.8 & 2.4 & 3.2 & 0.92 & 1.22 & 1.4 & 1.4 & 3.4 & 3.1 \\
\hline \multicolumn{11}{|l|}{ Fertilizer sources } \\
\hline $\mathrm{F}_{1}-\mathrm{RDF}$ & 72.6 & 77.9 & 9.1 & 13.2 & 3.47 & 5.02 & 7.7 & 9.7 & 39.2 & 42.8 \\
\hline $\mathrm{F}_{2}$-Placement of Urea-DAP briquettes & 75.2 & 80.6 & 13.5 & 17.7 & 5.12 & 6.74 & 9.0 & 10.9 & 43.3 & 47.3 \\
\hline $\mathrm{F}_{3}$-Placement of Urea-suphala briquettes & 73.7 & 79.2 & 11.1 & 15.0 & 4.21 & 5.70 & 8.6 & 10.6 & 42.0 & 45.7 \\
\hline $\operatorname{CD}(p=0.05)$ & 2.0 & 2.1 & 1.0 & 1.5 & 0.38 & 0.56 & 0.7 & 0.6 & 2.23 & 2.3 \\
\hline
\end{tabular}

the rest of the treatments in both the years. This is because of incorporation of weeds while puddling operation, their suppression due to maintenance of water level in the puddled field, proper plant spacing and optimum plant population. The leaf area was significantly highest with transplanting followed by Thomba method and SRI technique, than premonsoon dibbling of seeds and dibbling of seeds with the onset of monsoon. Pre-monsoon dibbling of seeds $\left(\mathrm{T}_{2}\right)$ and dibbling of seeds with the onset of monsoon were on par with each other during both years. The increased leaf area in transplanting is due to better absorption of nutrients as a result of more foraging roots. Transplanting, SRI technique and Thomba method recorded similar but significantly higher number of tillers hill ${ }^{-1}$ composed to pre-monsoon dibbling of seeds and dibbling of seeds with the onset of monsoon. The higher tiller production with transplanting might be due to better inducement of root growth for anchorage. This leads to better nutrient and water uptake and ultimately in higher number of tillers. These results are in agreement with that of reported by Singh et al. (2006). Total dry matter production at harvest was similar under transplanting, Thomba method and SRI technique and was significantly superior to pre-monsoon dibbling of seeds and dibbling of seeds with the onset of monsoon. However, in 2009 SRI technique, was on par with pre-monsoon dibbling of seeds but was significantly superior to dibbling of seeds with the onset of monsoon. Higher dry matter accumulation in transplanting method is because of to significant increase in morphological parameters which are responsible for the photosynthetic capacity of the plant thereby increasing the biological yield. These results are in 
confirmity with the results reported by Singh et al. (2006).

The beneficial effect of transplanting method in enhancing the growth through increased height, leaves, number of tillers, leaf area and dry matter production ultimately reflected in higher yield attributing characters viz., number of panicles hill $^{-1}$, length of panicle, number of filled grains panicle ${ }^{-1}$, number of unfilled grains panicle ${ }^{-1}$, weight of filled grains panicle ${ }^{-1}$ and test weight. The grain yield of rice is a function of yield attributes of an individual plant viz., number of panicles hill $^{-1}$, length of panicle, number of filled grains panicle ${ }^{-1}$, weight of filled grains panicle ${ }^{-1}$ and test weight and ultimately the grain yield obtained from the plant. Transplanting was on par with Thomba method and SRI technique in respect of number of panicles hill ${ }^{-1}$, length of panicle, number of filled grains panicle ${ }^{-1}$, weight of filled grains panicle ${ }^{-1}$ and test weight, and was significantly superior to pre monsoon dibbling of seeds and dibbling of seeds on the onset of monsoon (Table 2).

Transplanting method of crop establishment gave higher

Table 2: Number of panicles hill ${ }^{-1}$, length of panicle $(\mathrm{cm})$, number of filled grains panicle ${ }^{-1}$, weight of filled grains panicle ${ }^{-1}$, number of unfilled grains panicle ${ }^{-1}$ and test weight $(\mathrm{gm})$ of rice at harvest Growth and yield attributing characters of rice as influenced by different crop establishment and fertilizer treatments

\begin{tabular}{|c|c|c|c|c|c|c|c|c|c|c|c|c|}
\hline \multirow[t]{2}{*}{ Treatments } & \multicolumn{2}{|c|}{$\begin{array}{l}\text { No. of } \\
\text { panicles } \\
\text { hill }^{-1}\end{array}$} & \multicolumn{2}{|c|}{$\begin{array}{l}\text { Length of } \\
\text { panicle }(\mathrm{cm})\end{array}$} & \multicolumn{2}{|c|}{$\begin{array}{l}\text { Number of } \\
\text { filled grains } \\
\text { panicle }^{-1}\end{array}$} & \multicolumn{2}{|c|}{$\begin{array}{l}\text { Weight of } \\
\text { filled grains } \\
\text { panicle-1 }\end{array}$} & \multicolumn{2}{|c|}{$\begin{array}{c}\text { No. of } \\
\text { unfilled grains } \\
\text { panicle }{ }^{-1}\end{array}$} & \multicolumn{2}{|c|}{$\begin{array}{l}\text { Test Weight } \\
\text { (g) }\end{array}$} \\
\hline & 2009 & 2010 & 2009 & 2010 & 2009 & 2010 & 2009 & 2010 & 2009 & 2010 & 2009 & 2010 \\
\hline \multicolumn{13}{|l|}{ Crop establishment methods } \\
\hline $\mathrm{T}_{1}$-Transplanting & 9.71 & 11.69 & 25.23 & 25.16 & 143.78 & 152.33 & 3.73 & 3.96 & 21.44 & 24.11 & 25.91 & 26.00 \\
\hline $\begin{array}{l}\mathrm{T}_{2} \text {-Pre monsoon dibbling } \\
\text { of seeds }\end{array}$ & 7.37 & 9.38 & 22.33 & 22.98 & 104.56 & 112.22 & 2.68 & 2.88 & 21.22 & 22.78 & 25.63 & 25.70 \\
\hline $\begin{array}{l}\mathrm{T}_{3} \text {-Dibbling of seeds on the } \\
\text { onset of monsoon }\end{array}$ & 6.09 & 8.02 & 20.99 & 21.02 & 96.56 & 99.33 & 2.47 & 2.55 & 22.33 & 23.78 & 25.64 & 25.69 \\
\hline $\mathrm{T}_{4}$-Thomba method & 9.36 & 11.40 & 24.12 & 24.79 & 141.00 & 142.44 & 3.64 & 3.68 & 21.67 & 23.22 & 25.82 & 25.87 \\
\hline $\mathrm{T}_{5}$-SRI technique & 9.59 & 11.58 & 24.39 & 24.33 & 132.67 & 135.89 & 3.42 & 3.52 & 21.89 & 22.00 & 25.80 & 25.88 \\
\hline $\mathrm{CD}(p=0.05)$ & 1.42 & 1.39 & 2.02 & 1.37 & 18.55 & 22.08 & 0.48 & 0.56 & N.S. & N.S. & 0.09 & 0.10 \\
\hline \multicolumn{13}{|l|}{ Fertilizer sources } \\
\hline $\mathrm{F}_{1}-\mathrm{RDF}$ & 7.66 & 9.67 & 22.38 & 22.85 & 107.73 & 109.33 & 2.77 & 2.82 & 20.07 & 24.20 & 25.70 & 25.75 \\
\hline $\begin{array}{l}\mathrm{F}_{2} \text {-Placement of Urea-DAP } \\
\text { briquettes }\end{array}$ & 9.02 & 10.97 & 24.46 & 24.47 & 135.80 & 141.73 & 3.51 & 3.67 & 22.07 & 22.60 & 25.81 & 25.88 \\
\hline $\begin{array}{l}\mathrm{F}_{3} \text {-Placement of Urea- } \\
\text { suphala briquettes }\end{array}$ & 8.59 & 10.60 & 23.40 & 23.65 & 127.60 & 134.27 & 3.29 & 3.47 & 23.00 & 22.73 & 25.78 & 25.85 \\
\hline $\mathrm{CD}(p=0.05)$ & 0.65 & 0.63 & 1.56 & 1.23 & 14.76 & 12.24 & 0.38 & 0.31 & N.S. & N.S. & 0.06 & 0.05 \\
\hline General Mean & 8.42 & 10.41 & 23.41 & 23.66 & 123.71 & 128.44 & 3.19 & 3.32 & 21.71 & 23.18 & 25.76 & 25.83 \\
\hline
\end{tabular}

grain yield $\left(50.21\right.$ and $\left.54.95 \mathrm{q} \mathrm{ha}^{-1}\right)$ during both years followed by Thomba method and SRI technique. These treatments produced similar but significantly higher grains yield than other treatments except, SRI technique on par with premonsoon dibbling of seeds but found significantly superior to dibbling of seeds with the onset of monsoon. In case of first year and pooled mean, pre-monsoon dibbling of seeds was found significantly superior to dibbling of seeds with the onset of monsoon whereas during second year, both the treatment produced similar grain yield. The increase in grain yield under transplanting over Thomba method, SRI technique, pre-monsoon dibbling of seeds and dibbling of seeds with the onset of monsoon was to the tune of 1.0, 3.7, 10.6 and $17.4 \%$, respectively.. These results are in consonance with those of Singh et al. (2006). The Straw and biological yield
(Table 3) under transplanting of rice was significantly superior compared to pre-monsoon dibbling of seeds and dibbling of seeds with the onset of monsoon and was on par with Thomba method and SRI technique. Increase in straw yield under transplanting over Thomba method, SRI technique, pre monsoon dibbling of seeds and dibbling of seeds with the onset of monsoon was 1.0,1.6, 7.6 and $12.1 \%$, respectively. This might be due to increased morphological characters viz., plant height, number of leaves hill ${ }^{-1}$, number of tillers and dry matter production hill ${ }^{-1}$ observed under transplanting. Similar findings were also reported by Singh et al. (2003).

The uptake of $N, P$ and $K$ recorded was maximum in transplanting method, of crop establishment which was at significantly superior over pre-monsoon dibbling of seeds and dibbling of seeds on the onset of monsoon but was on 


\begin{tabular}{|c|c|c|c|c|c|c|c|c|c|}
\hline \multirow[t]{2}{*}{ Treatments } & \multicolumn{3}{|c|}{ Grain yield (q ha-1) } & \multicolumn{3}{|c|}{ Straw yield (q ha ${ }^{-1}$ ) } & \multicolumn{3}{|c|}{ Biological yield $\left(q\right.$ ha $^{-1}$ ) } \\
\hline & 2009 & 2010 & Mean & 2009 & 2010 & Mean & 2009 & 2010 & Mean \\
\hline \multicolumn{10}{|l|}{ Crop establishment methods } \\
\hline $\mathrm{T}_{1}$-Transplanting & 50.21 & 54.95 & 52.58 & 59.89 & 64.07 & 61.98 & 110.11 & 119.02 & 114.56 \\
\hline $\mathrm{T}_{2}$-Pre monsoon dibbling of seeds & 45.81 & 48.18 & 46.99 & 55.69 & 58.85 & 57.27 & 101.49 & 107.03 & 104.26 \\
\hline $\begin{array}{l}T_{3} \text {-Dibbling of seeds on the onset of } \\
\text { monsoon }\end{array}$ & 41.50 & 45.33 & 43.42 & 52.39 & 56.57 & 54.48 & 93.89 & 101.90 & 97.89 \\
\hline $\mathrm{T}_{4}$-Thomba method & 49.76 & 54.34 & 52.05 & 58.92 & 63.86 & 61.39 & 108.68 & 118.21 & 113.44 \\
\hline $\mathrm{T}_{5}-\mathrm{SRI}$ technique & 48.92 & 52.32 & 50.62 & 59.08 & 62.95 & 61.02 & 108.00 & 115.28 & 111.64 \\
\hline$C D(p=0.05)$ & 3.66 & 4.32 & 3.95 & 4.26 & 4.00 & 4.11 & 7.50 & 7.97 & 7.70 \\
\hline \multicolumn{10}{|l|}{ Fertilizer sources } \\
\hline $\mathrm{F}_{1}-\mathrm{RDF}$ & 44.91 & 49.19 & 47.05 & 54.47 & 59.19 & 56.83 & 99.38 & 108.38 & 103.88 \\
\hline$F_{2}$-Placement of Urea-DAP briquettes & 49.29 & 53.04 & 51.17 & 59.16 & 62.97 & 61.07 & 108.45 & 116.01 & 112.23 \\
\hline $\begin{array}{l}\text { F}_{3} \text {-Placement of Urea-suphala bri- } \\
\text { quettes }\end{array}$ & 47.53 & 50.84 & 49.18 & 57.95 & 61.62 & 59.79 & 105.48 & 112.46 & 108.97 \\
\hline $\mathrm{CD}(p=0.05)$ & 2.88 & 2.92 & 2.85 & 2.78 & 2.87 & 2.81 & 5.39 & 5.69 & 5.50 \\
\hline
\end{tabular}

par with SRI technique and Thomba method. Since uptake is a function of grain and straw yield and their nutrient content, the significant improvement in the content of these nutrients coupled with increased grain and straw yield increased the uptake of nutrients substantially. These results corrobarates the findings of Mangal Prasad et al. (1980) and Singh et al. (2006).

The available $\mathrm{N}, \mathrm{P}$ and $\mathrm{K}$ content of soil, after harvesting of rice were influenced significantly due to different crop establishment methods. The soil available $\mathrm{N}, \mathrm{P}$ and $\mathrm{K}$ after harvest of rice were maximum and significantly higher when crop was established by dibbling of seeds on the onset of monsoon as compared to pre-monsoon dibbling of seeds, SRI technique, Thomba method and transplanting. This could be attributed to lower uptake of $\mathrm{N}, \mathrm{P}_{2} \mathrm{O}_{5}$ and $\mathrm{K}_{2} \mathrm{O}$ under dibbling of seeds on the onset of monsoon and higher uptake of these nutrients under pre-monsoon dibbling of seeds, SRI technique, Thomba method and transplanting.

Transplanting of rice (Table 5 ) gave the highest gross returns ( $₹ 60447.5,65847.1$ and $63147.33 \mathrm{ha}^{-1}$ ). Net returns ( $₹ 20547.5,17457.8$ and $19002.72 \mathrm{ha}^{-1}$ ) and benefit to cost ratio $(1.52,1.36$ and 1.44$)$ followed by Thomba Method, pre monsoon dibbling of seeds, dibbling of seeds on the onset of monsoon and SRI technique during year 2009, 2010 and in case of pooled mean, respectively. Among all these establishment methods transplanting was found to be economically most profitable as its mean B:C ratio was 1.44 . The $\mathrm{B}: \mathrm{C}$ ratios recorded under Thomba method, pre monsoon dibbling of seeds, dibbling of seeds on the onset of monsoon and SRI technique were $1.41,1.40,1.34$ and 1.33 respectively. The increased gross returns, net returns and benefit to cost ratio due to transplanting method were mainly due to increased grain and straw yield under transplanting over rest of the establishment methods. Similar findings were also reported by Sanjay et al. (2006).

\subsection{Effect of fertilizer sources}

Application of urea-DAP briquettes recorded significantly highest plant height, number of leaves, number of tillers hill-1, leaf area and accumulation of dry matter compared to RDF and was on par with urea-suphala briquette (Table 1 ). In case of application of urea-DAP briquettes, it was placed deeply (5-6 $\mathrm{cm}$ ) in reduced zone of soil layer so that the plant nutrient was released slowly into soil, mostly under puddled condition in rice. Therefore, higher plant height under urea-DAP briquettes was recorded due to maximum amount of nitrogen availability as compare to other treatments. Similar findings were also reported by Bhagat (2005). The maximum plant height and number of leaves were found with treatment receiving urea-DAP a briquette which was on par with urea-suphala briquettes, but was significantly superior to RDF. However, urea-suphala briquette was on par with RDF during both the years. The enhancement in growth parameters could be due to balanced nutrition of the crop when fertilized through the briquettes. Similar results were also obtained by Pillai (2004). However leaf area at harvest was maximum in case of ureaDAP a briquette which was significantly superior to both ureasuphala briquettes and RDF. The highest number of tillers, leaves and leaf area due to application urea-DAP briquettes ultimately resulted in higher photosynthetic activity, the synthesis of higher amount of photosynthate by rice at all the crop growth stages. These results are in confirmity with Pillai (2004). The number of tillers hill $^{-1}$ were significantly influenced by the different fertilizer sources under study at harvest. The number of tillers was maximum in case of treatment urea- DAP 
briquettes $\left(F_{2}\right)$ which was on par with urea-suphala briquettes $\left(F_{3}\right)$ but found significantly superior to treatment RDF $\left(F_{1}\right)$ during both the years of experimentation. Total dry matter production hill $^{-1}$ at harvest, was significantly influenced due to different fertilizer sources. Urea-DAP briquettes produced maximum dry matter which was on par with urea-suphala briquettes but significantly superior to RDF during both the years. Pillai (2004) noted that dry matter production with application of $\mathrm{N}$ and $\mathrm{P}$ through UB-DAP briquette even at lower dose was as effective as that of broadcast application of higher dose of $\mathrm{N}$ and $\mathrm{P}$ fertilizers in lateritic soils of Konkan region.

Nitrogen element plays an important role in improving general growth and yield attributes and finally total yield of rice. The higher leaf area and dry matter accumulation in case of application of Urea-DAP briquettes might have ultimately resulted into more transformations in the sink resulting into significantly higher yield attributes viz. number of panicles hill $^{-1}$, length of panicle, number of filled grains panicle ${ }^{-1}$, weight of filled grains panicle ${ }^{-1}$ and test weight as compared to the treatments of Urea-suphala briquette and RDF treatments. Similar results in respect of more yield attributes due to UreaDAP briquettes were reported by Pillai (2004) and Bulbule et al. (2005).

Higher yield attributes under this treatment might be due to slow release of nitrogen which increases availability of nutrients. The higher value of growth and yield attributes under the treatment Urea-DAP briquettes reflected in significantly higher grain and straw yield of rice as compared to other fertilizers sources. Similar results were also obtained by Pillai (2004), Jagtap (2007) and Bulbule et al. (2008).

The grain yield of rice was significantly influenced owing to various fertilizer sources. Among different sources, urea- DAP briquettes gave higher grain yield $\left(49.29\right.$, and $53.04 \mathrm{q} \mathrm{ha}^{-1}$ during 2009 and 2010, respectively) followed by ureasuphala briquettes which were on par with each other but significantly superior to RDF. Urea-suphala briquettes and RDF were on par with each other during both the years and in the pooled mean. The mean increase in grain yield with application of urea-DAP briquettes over urea-suphala briquettes and application of RDF was 3.9 and $8.1 \%$, respectively. The increase in grain yield of rice due to application of urea-DAP briquettes may be accounted for significant improvement in yield attributes which finally resulted in higher grain yield. Similar results were reported by Talashilkar et,al. (2000) and Dhane et al. (2002). The straw and biological yield of rice followed the similar trend as that of grain yield (Table 3 ). The increase in straw yield under urea-DAP briquettes over urea-suphala briquettes and RDF was 2.1 and $7.0 \%$, respectively. The increase in straw and biological yield could be attributed to increase in growth characters due to application of urea-DAP briquettes. These results are in line with those reported by Talashilkar et, al. (2000) and Dhane et al. (2002). Interaction effects of crop establishment methods and fertilizer sources treatments were nonsignificant. Similarly, grain and straw yields were also not influenced significantly by treatment combinations.

The application of Urea-DAP briquettes to rice recorded significantly higher $\mathrm{N}, \mathrm{P}$ and $\mathrm{K}$ content in grain and straw over rest of the treatments except application of Ureasuphala briquettes. The higher content of $N, P$ and $K$ in grain and straw could be attributed to the fact that the crop absorbed proportionately higher amount of $\mathrm{N}, \mathrm{P}$ and $\mathrm{K}$ as pool of available nutrients increased in soil. These findings corroborate the reports of Pillai (2004), Jagtap (2007). The application of Urea-DAP briquettes recorded the highest uptake of nitrogen, phosphorous and potassium, however, it was at par with the application of Urea-suphala briquettes by rice grain, straw as well as total uptake and both these treatments significantly increased nitrogen, phosphorous and potassium uptake compared to rest of the treatments (Table 4). The increased uptake of these nutrients by rice was due to increase in grain and straw yield and $\mathrm{N}, \mathrm{P}$ and $\mathrm{K}$ content of grain and straw under the different fertilizer sources. These results are similar to those reported by Pillai (2004) and Jagtap (2007). The data on soil available N, P and $\mathrm{K}$ after harvest of rice showed slight increase under all the fertilizer sources treatments over their initial levels except available $\mathrm{K}$

Table 4: Economics of rice as influenced by different treatments

\begin{tabular}{|c|c|c|c|c|c|c|c|c|c|}
\hline \multirow[t]{2}{*}{ Treatments } & \multicolumn{3}{|c|}{ Gross Returns ( $\left(\right.$ ha $\left.^{-1}\right)$} & \multicolumn{3}{|c|}{ Net Returns (₹ ha-1) } & \multicolumn{3}{|c|}{ B: C ratio } \\
\hline & 2009 & 2010 & $\begin{array}{l}\text { Pooled } \\
\text { mean }\end{array}$ & 2009 & 2010 & $\begin{array}{l}\text { Pooled } \\
\text { mean }\end{array}$ & 2009 & 2010 & $\begin{array}{l}\text { Pooled } \\
\text { mean }\end{array}$ \\
\hline \multicolumn{10}{|l|}{ Crop establishment methods } \\
\hline $\mathrm{T}_{1}$-Transplanting & 60447.5 & 65847.1 & 63147.33 & 20547.5 & 17457.8 & 19002.72 & 1.52 & 1.36 & 1.44 \\
\hline $\mathrm{T}_{2}-$ Pre monsoon dibbling of seeds & 54956.0 & 57878.4 & 56417.22 & 18302.1 & 14559.8 & 16431.00 & 1.49 & 1.33 & 1.41 \\
\hline $\begin{array}{l}\mathrm{T}_{3} \text {-Dibbling of seeds on the onset } \\
\text { of monsoon }\end{array}$ & 50113.5 & 54520.8 & 52317.22 & 14683.8 & 11761.8 & 13222.89 & 1.42 & 1.27 & 1.34 \\
\hline $\mathrm{T}_{4}$-Thomba method & 59630.4 & 65162.8 & 62396.67 & 19455.0 & 16065.1 & 17760.06 & 1.48 & 1.32 & 1.40 \\
\hline $\mathrm{T}_{5}-\mathrm{SRI}$ technique & 58723.3 & 62852.2 & 60787.78 & 17202.3 & 13191.0 & 15196.67 & 1.41 & 1.26 & 1.33 \\
\hline $\mathrm{CD}(p=0.05)$ & 4520.12 & 5089.31 & 4737.76 & N.S. & 4235.18 & N.S. & - & - & - \\
\hline
\end{tabular}




\begin{tabular}{|c|c|c|c|c|c|c|c|c|c|}
\hline \multirow[t]{2}{*}{ Treatments } & \multicolumn{3}{|c|}{ Gross Returns (₹ ha-1) } & \multicolumn{3}{|c|}{ Net Returns (₹ ha-1) } & \multicolumn{3}{|c|}{ B: C ratio } \\
\hline & 2009 & 2010 & $\begin{array}{l}\text { Pooled } \\
\text { mean }\end{array}$ & 2009 & 2010 & $\begin{array}{l}\text { Pooled } \\
\text { mean }\end{array}$ & 2009 & 2010 & $\begin{array}{l}\text { Pooled } \\
\text { mean }\end{array}$ \\
\hline \multicolumn{10}{|l|}{ Fertilizer sources } \\
\hline $\mathrm{F}_{1}-\mathrm{RDF}$ & 53980.6 & 59028.2 & 56504.43 & 14186.6 & 11055.0 & 12620.83 & 1.36 & 1.23 & 1.29 \\
\hline $\mathrm{F}_{2}$-Placement of Urea-DAP briquettes & 59132.8 & 63643.9 & 61388.37 & 20640.6 & 17587.2 & 19113.93 & 1.53 & 1.38 & 1.45 \\
\hline $\begin{array}{l}\mathrm{F}_{3} \text {-Placement of Urea-suphala bri- } \\
\text { quettes }\end{array}$ & 57209.0 & 61084.8 & 59146.93 & 19287.2 & 15179.2 & 17233.23 & 1.51 & 1.33 & 1.42 \\
\hline $\operatorname{CD}(p=0.05)$ & 3503.14 & 3478.50 & 3446.66 & 2830.34 & 2898.99 & 2826.37 & - & - & - \\
\hline
\end{tabular}

under Urea-DAP briquettes as there was no addition of $\mathrm{K}$ in Urea-DAP briquettes treatment (Table 4). Rice supplied with Urea-DAP briquettes significantly increased soil available $\mathrm{N}$, and $\mathrm{P}$ after harvest of crop compared to RDF. However, it was at par with the treatment of Urea-suphala briquettes. In case of available $\mathrm{K}$ after harvest of rice showed slight increase under application of RDF which was at par with Urea-suphala briquettes and significantly higher than Urea-DAP briquettes. The increase in availability of these nutrients after harvest of rice might be due to mineralization and improvement in $\mathrm{N}$, $\mathrm{P}_{2} \mathrm{O}_{5}$ and $\mathrm{K}_{2} \mathrm{O}$ due to slow releasing and less leaching losses of the nutrients. Similar results were also reported by Pillai (2004) and Jagtap (2007) (Table 5).

Application of Urea-DAP briquettes gave maximum gross returns (Rs. 59132.8, 63643.9 and $61388.37 \mathrm{ha}^{-1}$ ). net returns (Rs. 20640.6. Rs. 17587.2 and Rs. 19133.93 ha $^{-1}$ ) and B:C ratio $(1.53,1.38$ and 1.45$)$ over rest of fertilizer sources treatments during year 2009, 2010 and pooled mean, respectively. These increased economic parameters were due to significant improvement in grain and straw yield of rice. Similar results were also reported by Bulbule et al. (2006) and Ghodke et

Table 5: Total uptake of nutrients $\left(\mathrm{kg} \mathrm{ha}^{-1}\right)$ by rice and available nutrient status $\left(\mathrm{kg} \mathrm{ha}^{-1}\right)$ in soil as influenced by different treatments

\begin{tabular}{|c|c|c|c|c|c|c|}
\hline \multirow[t]{2}{*}{ Treatments } & \multicolumn{3}{|c|}{ Grain yield (q ha-1) } & \multicolumn{3}{|c|}{ Straw yield (q ha-1) } \\
\hline & Nitrogen & Phosphorous & Potassium & Nitrogen & Phosphorous & Potassium \\
\hline \multicolumn{7}{|l|}{ Crop establishment methods } \\
\hline $\mathrm{T}_{1}$-Transplanting & 90.22 & 18.95 & 102.87 & 317.06 & 15.33 & 286.89 \\
\hline $\mathrm{T}_{2}$-Pre monsoon dibbling of seeds & 73.99 & 15.52 & 86.89 & 327.21 & 16.76 & 295.30 \\
\hline $\begin{array}{l}T_{3} \text {-Dibbling of seeds on the onset of mon- } \\
\text { soon }\end{array}$ & 64.47 & 13.51 & 77.73 & 333.86 & 17.75 & 302.37 \\
\hline $\mathrm{T}_{4}$-Thomba method & 88.61 & 18.61 & 101.12 & 317.95 & 15.53 & 288.50 \\
\hline $\mathrm{T}_{5}-\mathrm{SRI}$ technique & 85.11 & 17.86 & 98.98 & 320.38 & 15.85 & 289.80 \\
\hline$C D(p=0.05)$ & 12.08 & 2.54 & 13.15 & 9.53 & 1.12 & 9.62 \\
\hline \multicolumn{7}{|l|}{ Fertilizer sources } \\
\hline $\mathrm{F}_{1}-\mathrm{RDF}$ & 73.96 & 15.52 & 86.09 & 323.69 & 16.66 & 301.95 \\
\hline $\mathrm{F}_{2}$-Placement of Urea-DAP briquettes & 86.45 & 18.15 & 99.53 & 325.09 & 17.29 & 279.06 \\
\hline $\mathrm{F}_{3}$-Placement of Urea-suphala briquettes & 81.04 & 17 & 94.94 & 321.09 & 14.79 & 296.70 \\
\hline $\operatorname{CD}(p=0.05)$ & 8.59 & 1.81 & 9.11 & N.S. & 0.27 & 7.1 \\
\hline General Mean & 80.89 & 16.49 & 93.52 & 323.29 & 0.80 & 292.57 \\
\hline
\end{tabular}

al. (2008).

\section{Conclusion}

Growing kharif rice under upland situation, crop need to be established by transplanting method and amended with urea-DAP briquettes (@ 168.75 kg ha ${ }^{-1}$ ), to obtain higher yield. However, under inadequate rainwater for puddling,
Thomba method with urea-DAP briquettes (@ $168.75 \mathrm{~kg} \mathrm{ha}^{-1}$ ) is suitable, and under labour scarcity condition, pre-monsoon dibbling of seeds with urea-DAP briquettes (@ 168.75 kg $\mathrm{ha}^{-1}$ ) is one of the alternatives to conventional transplanting method under upland conditions. 


\section{References}

Bhagat, S.S., Khawale, V.S., Dongarkar, K.P., Gudhadhe, N.N., 2005. Effect of spacing and fertilizer briquette on growth and yield of lowland paddy. Journal of Soils and Crops, 15(2), 462-465.

Bulbule, A.V., Patil, V.S., Jangle, G. D., 2005. Efficient fertilizer management through deep placement as briquette for lowland rainfed transplanted rice. Journal of Maharashtra agricultural universities 30(3), 259-262.

Bulbule, A.V., Patil, V.S., Jangle, G.D., Purkar, J.K., 2006. Efficient Management of Nitrogenous Fertilizer in Lowland Rainfed Transplanted Rice under Rainfed Rice Ecosystem. Agricultural Science Digest 26(1).

Bulbule, A.V., Durgude, A.G., Patil, V.S., Kulkarni R.V., 2008. Fertilization of lowland transplanted rice through briquettes. crop research journal 35(1 \& 2), 1-5.

Dhane, S.S., Yadav, A.N., Mahale, D., 2002. Urea Briquettes containing diammonium Phosphate an important NP source for coastal saline soils. Journal of Maharashtra agriculture Universities 27(2), 226-228.

Ghodke, S.B., Sawant, A.C., Chavan, P.G., Pawar, P.P., 2008. Integrated nutrient management in transplanted hybrid rice Sahyadri-2. Journal Of Maharashtra Agricultural Universities 33(3), 325-327.

Jagtap, P.P., 2007. Effect of integrated use of manures, fertilizers and deep placement of UB-DAP on growth, yield, nutrient uptake and quality of Ratnagiri-1 rice (Oryza sativa.L.) in lateritic soils. M.Sc. (Agri.) Thesis submitted to Dr. B. S. Konkan Krishi Vidyapeeth, Dapoli
(MS), India.

Prasad, M., Prasad, R., 1980. Yield and Nitrogen Uptake by Rice as Affected by Variety, Method of Planting and New Nitrogen Fertilizers. Nutrient Cycling in Agroecosystems $1(4), 207-213$.

Pillai, M.G., 2004. Comparative study on the effect of glyricidia incorporation, Broadcast of fertilizers and deep placement of UB-DAP on yield, nutrient use efficiency and nutrient recovery of Sahyadri hybrid rice. M.Sc. (Agri.) Thesis submitted to Dr. B. S. K. K. V., Dapoli, India.

Sanjay, M.T., Prabhakar Shetty, T.K., Nanjappa, H.V., 2006. Investigation of crop establishment methods and weed management practices on productivity and economics in rice. MysoreJournal of Agricultural Sciences 42(1), 60-66.

Singh, R.P., Singh, C.M., Singh, A.K., 2003. Effect of crop establishment methods, weed management and splitting of $\mathrm{N}$ on rice and associated weeds. Indian Journal of weed science 35(1 and 2), 33-37.

Singh, Y.P., Singh, G., Singh, S.P., Kumar, A., Sharma, G., Singh, M.K., Mortimer, M., Johnson D.E., 2006. Effect of weed management and crop establishment methods on weed dynamics and grain yield of rice. Indian Journal of weed Science 38(1 and 2), 20-24.

Talashilkar, S.C., Savant, D.S., Dhamapurkar, V.B., Savant, N.K., 2000. Yield and nutrient uptake by rice as influenced by integrated use of calcium silicate slag and UB-DAP in acid lateritic soil. Journal of the Indian Society of Soil Science 48(4), 847-849. 